Bangladesh Journal of Neuroscience 2017; Vol. 33 (1): 13-17

\title{
Common Non-Neurological Medical Complications in Acute Ischemic Stroke Patients
}

\author{
HOSSAIN MA ${ }^{1}$, HANNAN MA² ${ }^{2}$ BISWAS PK ${ }^{3}$, JAHAN M4 ${ }^{4}$ KHAN MAM ${ }^{1}$
}

\begin{abstract}
:
Ischemic stroke patients suffer from different complications among which nonneurological medical complications are common along with stroke related neurological complications. This observational study was aimed to find out these non-neurological common medical complications of acute ischemic stroke patients admitted in hospital in this country. This study was conducted by every day observation of acute ischemic stroke patients admitted in the hospital. Medical complications were diagnosed on the basis of clinical features and laboratory findings. In acute ischemic stroke patients, development of medical complications is more common (60\%). Among them infective complications were found more than non-infective complications. Urinary tract infections $(17.8 \%)$, respiratory tract infection (17.8\%), mixed complications (13.3\%) were found commoner than other complications. Length of hospital stay (LOHS) was prolonged in those patients who developed these complications. These complications play a vital role in outcome of the patients.
\end{abstract}

Keywords: acute ischemic stroke, complication, infection, length of hospital stay.

\section{Introduction:}

Stroke is a major cause of death and disability worldwide ${ }^{1}$. Stroke is usually characterized by rapid onset of focal neurological deficit due to infarction or hemorrhage lasting more than 24 hours $^{2}$. The definition of stroke is clinical and laboratory studies including brain imaging are used to support the diagnosis ${ }^{3}$. Countries of low and middle income have the largest burden of stroke, accounting for more than $85 \%$ of stroke mortality worldwide ${ }^{4}$. Cause of mortality and morbidity depends upon different neurological and non-neurological complications of acute ischemic stroke (AIS) patients. Most of the time we are concerned about the neurological complications only, but nonneurological medical complications also play devastating impact in outcome of stroke patients ${ }^{5}$.

We have observed multiple medical complications like urinary tract infection, sepsis, respiratory tract infection, myocardial infarction etc in stroke patients. These complications cause deterioration of the patients. It is also strongly linked to a poor inpatient prognosis as well higher rate of complications lead to longer hospital stay and increase cost of care ${ }^{6-9}$.

Such type of study was not previously performed in Bangladesh. It is important to identify the common complications in-hospital of AIS patients to provide necessary informations regarding proper management of AIS patients.

\section{Materials and Methods:}

This observational study was conducted in the department of Neurology of Bangabandhu Sheikh Mujib Medical University (BSMMU), Dhaka, Bangladesh during January 2013 to December 2013 and received prior approval from Ethical Review Committee of BSMMU and all participants/ attendants gave informed written consent. All collected data were checked, edited and analyzed by using computer based SPSS software version 16.0. Data were presented by frequency distribution

1. Asstt. Professor of Neurology, NINS, Dhaka.

2. Professor, Department of Neurology, Bangabandhu Sheikh Mujib Medical University, Dhaka

3. Associate Professor of Medicine, Dhaka Medical College, Dhaka.

4. Lecturer, Dhaka Medical College, Dhaka.

5. Assistant Professor of Neurology, National Institute of Neurosciences Hospital, Dhaka 
and percentage. Parametric data was expressed in mean $\pm S D$. Categorical data was evaluated by Chi square test. Significance was defined by $p$ value $<0.05$.

A total of 90 AIS patients admitted in the Neurology department of BSMMU were included in this study. Sampling technique was purposive. Patients presented with first ever AIS, confirmed by CT scan/ MRI of brain from 01 day to 02 weeks were enrolled in this study. Hemorrhagic stroke patients were excluded from this study.

After selection of subjects, detailed history, clinical examinations and all other information's were taken in a prescribed data collection form. Relevant baseline investigations (e.g. - complete blood count, urine R/M/E etc.) were performed. Imaging study (CT/MRI) was done for diagnosis and categorization of stroke. AIS subtype is defined by Oxford shire Community Stroke Project classification (OCSP) criteria. Cerebral infarctions were divided into the following clinical categories: total anterior circulation infarcts (TACI), partial anterior circulation infarcts (PACl), lacunar infarcts ( $\mathrm{LACl})$, and posterior circulation infarcts (POCI). Modified Rankin Scale (mRS) was measured to see functional outcomes at fourteenth day of stroke. Patients were followed up every day to see any in-hospital medical complications eg. Respiratory Tract Infection (RTI), Urinary Tract Infection (UTI), Bed sore, Electrolyte Imbalance (Sodium or Potassium abnormalities) and MI. Diagnosis of this complications were made by clinical findings, expert opinion and appropriate laboratory reports like Urine R/E and C/S for UTI, Chest $\mathrm{X}$ ray and Sputum C/S for RTI, ECG and/or Troponin I for MI, Serum Electrolytes, d-dimer, duplex study of lower limb vessels, Stool R/E etc. Length of hospital stay (LOHS) was measured from admission to discharge day of the patient.

\section{Results:}

Out of the 90 AIS patients, majority $36(40 \%)$ were belonged to age group of 61-70 years. The mean age was found 59 years with range from 30 to 75 years (Table I).

It was observed that more than half $49(54 \%)$ were male and $41(46 \%)$ were female. Male to female ratio was $1.2: 1$. It also showed that $49(54 \%)$ patients came from rural area and $41(46 \%)$ came from urban area (Table I).

Table-I

Socio-demographic characteristics of the patients $(n=90)$

\begin{tabular}{llcc}
\hline Characteristics & \multicolumn{3}{c}{$\begin{array}{c}\text { No. of } \\
\text { respondents }\end{array}$} \\
\hline Sex & Male & 49 & Percentage \\
& Female & 41 & 44.4 \\
Age & $\leq 40$ & 7 & 7.8 \\
& $41-50$ & 9 & 10.0 \\
& $51-60$ & 34 & 37.8 \\
& $61-70$ & 36 & 40.0 \\
Residence & $>70$ & 4 & 4.4 \\
& Urban & 41 & 45.6 \\
& Rural & 49 & 54.4 \\
\hline
\end{tabular}

It was observed that non-smoker was found in $43(47.8 \%)$ patients, current smoker was $30(33.3 \%)$ and former smoker $17(18.9 \%)$.

It was observed that $52(57.8 \%)$ patients had hypertension and $38(42.2 \%)$ had no hypertension.

This study revealed that $32(35.6 \%)$ patients had diabetes mellitus (DM).

By Oxford shire Community Stroke Project classification (OCSP), It was observed that $4(4.4 \%)$ TAC, 15(16.7\%) LAC, 51(56.7\%) PAC, 14(15.6\%) $\mathrm{POC}$ and $6(6.6 \%)$ syndromes.

It was observed that majority $38(42.2 \%)$ of patients had hospital stay of 11-15 days. The mean hospital stay was found in $13.68 \pm 6.6$ days (Table II).

Table-II

Distribution of the patients by length of hospital stay $(n=90)$

\begin{tabular}{lcc}
\hline $\begin{array}{l}\text { Length of Hospital } \\
\text { stay (days) }\end{array}$ & $\begin{array}{c}\text { Number of } \\
\text { patients }\end{array}$ & Percentage \\
\hline$\leq 5$ & 3 & 3.3 \\
$6-10$ & 23 & 25.6 \\
$11-15$ & 38 & 42.2 \\
$16-20$ & 4 & 4.4 \\
$21-25$ & 18 & 20.0 \\
$>25$ & 4 & 4.4 \\
Mean \pm SD & \multicolumn{2}{c}{$13.68 \pm 6.6$} \\
Range (min, max) & \multicolumn{3}{c}{$(4,31)$} \\
\hline
\end{tabular}

Table Il shows length of hospital stay of the patients. It was observed that majority $38(42.2 \%)$ of patients 
had hospital stay of $11-15$ days. The mean hospital stay was found in $13.68 \pm 6.6$ days.

Medical complications were found in $54(60 \%)$ patients. No complication was found in $36(40 \%)$ patients. This present study results showed that UTI and RTI were found same, is $16(17.8 \%)$ of patients. Bed sore was found in $3(3.3 \%)$ patients. Electrolyte Imbalance was found in $2(2.2 \%)$ patients. Others/mixed complications were found in $12(13.3 \%)$ patients. Gastroenteritis was $4(4.4 \%)$ and myocardial infarction was 1 (1.11\%) (Table IV).

\section{Table-III}

In-hospital medical complications in AIS patients $(n=90)$

\begin{tabular}{lcc}
\hline $\begin{array}{l}\text { Medical } \\
\text { Complications }\end{array}$ & $\begin{array}{c}\text { Number of (N) } \\
\text { patients }\end{array}$ & Percentage \\
\hline Complications & 54 & 60 \\
No complication & 36 & 40 \\
\hline
\end{tabular}

Table III Shows in-hospital medical complications were found in $54(60 \%)$ patients, no complications in $36(40 \%)$ patients.

Table-IV

Different in-hospital complications in AIS patients $(n=90)$

\begin{tabular}{lcc}
\hline In-hospital complications & $\mathrm{n}$ & $\%$ \\
\hline Gastroenteritis & 4 & 4.4 \\
UTI & 16 & 17.8 \\
RTI & 16 & 17.8 \\
Bed sore & 3 & 3.3 \\
Electrolyte Imbalance & 2 & 2.2 \\
MI & 1 & 1.1 \\
Others/Mixed complication & 12 & 13.3 \\
\hline
\end{tabular}

UTI- Urinary Tract Infection, RTI- Respiratory tract infection, MI- Myocardial infarction.

\section{Discussion:}

Frequency of stroke rises exponentially with increasing age ${ }^{10}$. Majority of the study subject $(40 \%)$ were in seventh decade and the mean age was 59 years varied from 30 to 75 years (Table I). Similarly Hossain et al. in Faridpur Medical College showed highest incidence of stroke was between the sixth and seventh decade ${ }^{11,12}$. Kundu et al. in a Bangladeshi study showed $16 \%$ were young stroke (age<40years) and most patients $(54 \%)$ were at and above 60 years of age ${ }^{13}$. Basu et al. obtained that median age was 60 years, mean age $60 \pm 13$ years varied from $25-88$ years, which is closely resembled with the present study ${ }^{14}$. On the other hand, Gentile et al. showed the mean age was $65.7 \pm 13.6$ years varied from 20 to 101 years. In another study conducted in University of south Carolina, USA, Bhatt and Rizvi found the average age of AIS patients was 67.8 years, which are higher with the current study, this may be due to increased life expectancy, and geographical influences may have significant impacts to developed AIS of their study patients ${ }^{15}$.

In current study it was observed that AIS was predominant in male subjects, where $54 \%$ and $46 \%$ patients were male and female respectively and male to female ratio was 1.2:1. Similar observations regarding the sex incidence were also made by Basu et al. where they found $57.0 \%$ were male and $43.0 \%$ were female ${ }^{14}$. However, Gentile et al. and Bhatt and Rizvi were found $55.0 \%$ and $57.0 \%$ patients were female respectively. ${ }^{15,3}$ More than a half $(54 \%)$ of the patients attended from rural area and $46 \%$ came from urban. These findings are almost similar of the study done by Hossain et al ${ }^{12}$. The reason of higher percentage of AIS in rural patients might be that, lack of knowledge regarding risk factors due to low economical condition. It was observed that non-smoker was found in $47.8 \%$ patients, current smoker was $33.3 \%$ and former smoker $18.9 \%$. In Stollberger et al. study showed $9.0 \%$ patients were current smoker. Hossain et al. showed $20.75 \%$ current smoker in a Bangladeshi study ${ }^{12}$.

This study findings showed that more than one third (35.6\%) of the patients had DM. Basu et al. from Kolkata and Bhatt and Rizvi from South Carolina showed $26.0 \%$ and $51.4 \%$ had a known history of DM respectively ${ }^{14,15}$. Stollberger et al. in 2005 found that $30 \%$ patients had a history of $\mathrm{DM}^{20}$. Gentile et al. obtained DM $39 \%$ in their study patients $^{3}$. Hossain et al. showed $21 \%$ DM in stroke patients at Faridpur Medical College ${ }^{12}$. Kundu et al. showed DM is found in $99(20 \%)$ patients $^{13}$. And of these 99 patients only 57 (12\%) patients 
were known diabetic and the remaining patients were labeled as diabetic after admission.

In this study, it was observed that $57.8 \%$ patients had hypertension and $42.2 \%$ patients were normotensive. Similarly, Stollberger et al. found that $66.0 \%$ patients were hypertensive ${ }^{20}$. Basu et al. and Gentile et al. showed that $74.0 \%$ and $73.8 \%$ patients were known hypertensive respectively, which is higher with the current study ${ }^{3,13}$. In a study conducted at Faridpur Medical College showed $63 \%$ were hypertensive in stroke patients. ${ }^{12}$ In the study by Kundu et al. hypertensive patients were found $69.60 \%$ (284) out of 500 patients $^{13}$.

In this present study it was observed that majority $(42.2 \%)$ of patients had hospital stay of $11-15$ days and the mean duration of hospital stay was $13.68 \pm 6.6$ days varied from 4-31 days. Similarly, Stollberger et al. showed duration of hospitalization was 13 days varied from $9-20$ days $^{20}$. Gentile et al. and Bhatt and Rizvi (2010) observed the mean length of hospital stay were $7.40 \pm 8.15$ days and $6.12 \pm 4.2$ days respectively, which are lesser with the current study ${ }^{3,15}$.

In this study, 54(60\%) patients developed complications. This present study results showed that UTI and RTI were found same, is $16(17.8 \%)$ of patients. Bed sore was found in $3(3.3 \%)$ patients. Electrolyte Imbalance was found in 2 $(2.2 \%)$ patients. Others/mixed complications were found in 12 (13.3\%) patients. Gastroenteritis was $4(4.4 \%)$ and myocardial infarction was $1(1.11 \%)$. Stollberger et al. at Austria studied 992 patients of stroke where $12 \%$ had UTI, mixed complications in $29 \%$, but RTI in stroke patients is $14 \%^{20}$. These findings are similar with current study.

\section{Conclusion:}

Ischemic stroke patients suffer from both neurological and non-neurological medical conditions. Our observation at a large urban teaching hospital showed non-neurological medical complications of acute ischemic stroke patients is very common in this country. Among them infective complications were found more common than noninfective complications. Urinary tract infections (17.8\%), respiratory tract infection (17.8\%), mixed complications (13.3\%) were found more common than other complications. Length of hospital stay (LOHS) was prolonged in the patients who developed these complications. These complications play a vital role in outcome of acute ischemic stroke patients. This study should be conducted in a large scale in different hospitals for better understanding of different complications of so that proper steps can be taken to reduce mortality and morbidity of ischemic stroke patients.

\section{References}

1. Fauci AS, Braunwald E, Kasper DL, Hauser SL, Longo DL, Jameson JL. Cerebrovascular disease. In: Harrison's Principles of Internal Medicine 17th Edition, McGraw Hill, New York. 2008.

2. Smith WS, Joey D, English S. Cerebrovascular disease. In: Harrison's Principles of Internal Medicine 18th Edition, McGraw Hill, New York. 2011; 3270-94.

3. Gentile NT, Seftchick MW, Huynh T, Kruus LK, Gaughan J. 'Decreased mortality by normalizing Blood Glucose after Acute Ischemic Stroke'. AcadEmerg Med. 2006; 13: 174-80.

4. Williams LS, Rotich J, Fineberg N, Espay A, Bruno A, Fineberg SE, et al. Effects of admission hyperglycemia on mortality and costs in Acute Ischemic Stroke. Neurology.2002; 59: 67-71.

5. Frederic MW. Cerebrovascular disease. In: Cardiac and Vascular Disease Conn HLJR and Horwitzo (eds). Lea and Febiger, Philladelphia. 1971; 1473-99.

6. Wolf PA, Cobb JL, Agostine D. Epidemiology of stroke; Stroke $2^{\text {nd }}$ Edition, Barnett HJM and Mohr JP (eds). Churchill Livingstone, Edinburgh. 1992; 3-27.

7. Houseley E. Definition of risk factors in stroke; Stroke Gillingam FJ and Mawdsley C (eds), Churchill Livingstone, New York. 1976; 251-60.

8. Grotta JC. Post-stroke management concerns and outcomes. Geriatrics. 1988; 43:40-48. 
9. Sacco RL, Wolf PA, Kannel WB, McNamara PM. Survival and recurrence following stroke: the Framingham study. Stroke. 1982; 13: 290-295.

10. Silver FL, Norris JW, Lewis AJ, Hachinski VC. Early mortality following stroke: a prospective review. Stroke. 1984; 15:492-496.

11. Allen CM. Predicting the outcome of acute stroke: a prognostic score. J NeurolNeurosurg Psychiatry.1984; 47:475480.

12. Hossain AM, Ahmed NU, Rahman M, Islam MR, Sadhya G, Fatema K. Analysis of sociodemographic and clinical factors associated with hospitalized stroke patients of Bangladesh. Faridpur Med. Coll. J. 2011; 1: 19-23.

13. Kundu NC, Ahmed Q, Sen M. 'Study of stroke and its risk factors among admitted patients in a tertiary level hospital'. Bangladesh Journal of Neuroscience. 2010; 26: 86-91.

14. Basu S, SanyalD, Roy K, Bhattacharya K. Is post-stroke hyperglycemia a marker of stroke severity and prognosis: A pilot study'. Neurology AISa. 2007; 12: 13-19.
15. Bhatt $H$, Rizvi AA. 'Average inpatient glucose levels during the first 72 hours Clinical Outcomes and Length of Hospital Stay in Patients with Acute Ischemic Stroke'. Int J Diabetes \&Metab.2010; 18: 13-17.

16. Hart CL, Hole DJ, Smith GD. Influence of socioeconomic circumstance in early and later life on stroke risk among men in a Scottish cohort study. Stroke. 2000; 31(9): 2093-97.

17. Casper M, Wing S, Strogatz D. Variation in the magnitude of black- white differences in stroke mortality by community occupational structure. J Epidemiol Community Health.1991; 45: 02-307.

18. Shaper AG. Risk factors for stroke in middle age British men.BMJ.1991; 302: 1111-16.

19. Chapman J. Epidemiology of vascular lesions affecting the central nervous system: The occurrence of stroke in a sample population under observation for cardiovascular disease. Am JPublic Health.1966; 55: 191-01.

20. Stollberger C, Exner I, Finsterer J, Slany J, StegerC. 'Stroke in diabetic and non-diabetic patients: Course and prognostic value of admission serum glucose'. Annals of Medicine.2005; 37: 357-64. 